\title{
Natural Enemies of Chrysomya albiceps (Wiedemann) (Diptera: Calliphoridae) Collected in States Goiás and Minas Gerais, Brazil
}

\author{
C. H. Marchiori ${ }^{1}$ \\ ${ }^{1}$ Instituto Federal Goiano, Universidade Federal de Goiás, Instituto de Patologia Tropical e Saúde Pública, \\ Goiânia, Goiás, Brazil \\ Correspondence: C. H. Marchiori, Instituto Federal Goiano, Universidade Federal de Goiás, Instituto de Patologia \\ Tropical e Saúde Pública, Goiânia, Goiás, Brazil. E-mail: chmarchiori@yahoo.com.br
}

Received: November 18, $2014 \quad$ Accepted: November 30, 2014 Online Published: December 3, 2014

doi:10.5539/ijb.v7n1p78

URL: http://dx.doi.org/10.5539/ijb.v7n1p78

\begin{abstract}
Chrysomya albiceps (Wiedemann) (Diptera: Calliphoridae) is of great medical importance because it produces myiasis. It has a significant role as a predator of other dipterous larvae. Moreover, this dipterous insect is of great importance with regard to public health because it mechanically carries pathogens to humans. This study had the objective of ascertaining the species of parasitoids of $C$. albiceps in human feces, cattle liver, cattle kidney, chicken viscera, fish and pig carcasses in Goiás and Minas Gerais, from October 1999 to November 2013. Pupae were obtained by means of the flotation method. They were individually placed in gelatin capsules until the adult flies or their parasitoids emerged. Nasonia vitripennis (Walker) (Hymenoptera: Pteromalidae) was the most frequent species with a percentage of $42.4 \%$. Pachycrepoideus vindemmiae was the species that showed a highest percentage of parasitism.
\end{abstract}

Keywords: biocontrol, insects pests, baits, parasitoids, flotation

\section{Introduction}

Species of blowflies are popularly known in Brazil as gadflies. Their larvae may be biontophagous or scavengers and can cause obligatory or optional myiasis, thus taking on great importance regarding animal health (Greenberg, 1971, Mabika et al., 2012).

Chrysomya albiceps (Wiedemann) (Diptera: Calliphoridae) is of great medical importance because it produces myiasis. It has a significant role as a predatory other dipterous larvae. Moreover, this dipterous insect is of great importance with regard to public health because it mechanically carries pathogens to humans and animals (Queiroz et al., 1996; Mabika et al., 2012; Radhakrishnan et al., 2012; Marchiori, 2014a, 2014b, 2014c).

The adults of $C$. albiceps feed on a wide variety of substances, including flower nectar, urban garbage, fallen fruit, human feces and other animal products such as liver, beef and fish (Queiroz, 1996; Mabika et al., 2012; Radhakrishnan et al., 2012).

Parasitoids are responsible for reducing the populations of dipterous that proliferate on various substrates. Evaluation of these species for natural control over these insects pests is important for enabling studies that aim towards subsequent selection of species for use in biological control programs (Marchiori et al., 2000).

The aim of this study was to report on parasitoids of C. albiceps collected in the states of Goiás and Minas Gerais, Brazil.

\section{Material and Methods}

\subsection{Experiment with Pig Carcasses}

In a natural area, two pig carcasses (Sus scrofa) scavengers. Underneath the cages, metal trays with sawdust were placed to collect the pupae. The pupae were extracted by means of flotation in water. The pupae were individually placed in gelatin capsule. To obtain the parasitoids, the contents of the traps were placed in plastic containers with a layer of sand for use as a substrate for transformation of the larvae into pupae. This sand was sifted after being in the fields for 15 days and the pupae were extracted from it and were individually placed in gelatin capsules (size number 00 ) in order to obtain the dipterous and/or parasitoids. This substrate was used as best attract the species C. albiceps 


\subsection{Experiment with Human Feces, Cattle Kidneys, Cattle Liver, Chicken Viscera and Fish}

The dipterous were collected by using traps, made of dark cans measuring $19 \mathrm{~cm}$ in height and $9 \mathrm{~cm}$ in diameter, with two openings resembling blinders, located in the lowest third of the can, to allow dipterous to enter. The top of the can was connected to a nylon funnel that was open at both ends, with the base pointing down. This was wrapped in plastic bags, so that when they were removed, the dipterous and parasitoids could be collected. The following items were used as baits: human feces, cattle kidneys, cattle liver, chicken viscera and fish which were placed inside the cans, over a layer of earth. Five traps were used and they were hung on trees at a height of one meter above the ground, two meters apart from each other. The insects collected were taken to the laboratory, sacrificed with ethyl ether and kept in $70 \%$ alcohol for further identification. To obtain the parasitoids, the contents of the traps were placed in plastic containers with a layer of sand for use as a substrate for transformation of the larvae into pupae. This sand was sifted after being in the fields for 15 days and the pupae were extracted from it and were individually placed in gelatin capsules (size number 00 ) in order to obtain the dipterous and/or parasitoids. These substrates were used as best attract the species C. albiceps.

\subsection{Percentage of Parasitism}

The total percentage parasitism was calculated by means of the number of pupae parasitized, divided by the total number of pupae collected, and multiplied by 100 . The percentage parasitism of each parasitoid species was calculated by means of the number of pupae parasitized per species of parasitoid, divided by the total number of pupae.

\subsection{Collection Period}

Years and Monthly of collection: 1999 (October and December) - 2001 (March, April, May and June) - 2003 (August and September) - 2004 (April, May, November and December) - 2005 (March, April, May, June, July, August, September, October and December) - 2006 January, February, March, April, May, June, July, August, September, October, November and December) 2007 (January, February, March, April, May, June, July, August, September, October, November and December), 2008 (January, February, March, April and May) and 2013 (November).

\section{Results and Discussion}

From October 1999 to November 2013, we obtained 5314 pupae of C. albiceps, from which 132 pupae 824 parasitoids emerged (Table 1).

Table 1. Parasitoids of Chrysomya albiceps collected in states of Goiás and Minas Gerais, from October 1999 to November 2013

\begin{tabular}{|c|c|c|c|c|c|c|}
\hline $\begin{array}{l}\text { Total of pupae } \\
\text { - C. albiceps }\end{array}$ & Substrates & Parasitoids & $\begin{array}{l}* \text { Years and Months } \\
\text { of Collection }\end{array}$ & $\begin{array}{l}\text { Number of } \\
\text { individuals }\end{array}$ & $\begin{array}{l}\text { Number of } \\
\text { pupae parasitizing }\end{array}$ & $* * * \%$ \\
\hline \multirow[t]{2}{*}{168} & Feces & H. herbertii & $\begin{array}{l}2003(\mathrm{~A}, \mathrm{~S})- \\
2004(\mathrm{~A}, \mathrm{M})\end{array}$ & $27 * *$ & 04 & 1.1 \\
\hline & & Trichopria sp. & $\begin{array}{l}2004(\mathrm{~A}, \mathrm{~N}, \mathrm{D})- \\
2005(\mathrm{M}, \mathrm{A})\end{array}$ & 25 & 25 & 14.9 \\
\hline \multirow[t]{2}{*}{3941} & Carcass & P. egeria & $1999(\mathrm{O}, \mathrm{D})$ & 5 & 5 & 0.1 \\
\hline & & S. endius & $1999(\mathrm{O}, \mathrm{D})$ & 7 & 7 & 0.2 \\
\hline 1088 & $\begin{array}{l}\text { Cattle kidney and } \\
\text { Cattle liver }\end{array}$ & N. vitripennis & $\begin{array}{l}2005 \\
(\mathrm{M}, \mathrm{A}, \mathrm{M}, \mathrm{J}, \mathrm{J}, \mathrm{A}, \mathrm{S}, \mathrm{O}, \mathrm{D})\end{array}$ & $692 * *$ & 56 & 5.1 \\
\hline 29 & Chicken viscera & B. podagrica & $2001(\mathrm{M}, \mathrm{A}, \mathrm{M}, \mathrm{J})$ & 04 & 04 & 13.8 \\
\hline 45 & $\begin{array}{l}\text { Carcass and } \\
\text { Fish }\end{array}$ & P. vindemmiae & $\begin{array}{l}2006(\mathrm{~J}-\mathrm{D}), 2007(\mathrm{~J}-\mathrm{D}), \\
2008(\mathrm{~J}, \mathrm{~F}, \mathrm{M}, \mathrm{A}, \mathrm{M})\end{array}$ & 30 & 30 & 66.6 \\
\hline \multirow[t]{2}{*}{43} & Catlle liver & Tachinobia sp. & $2013(\mathrm{~N})$ & $30 * *$ & 1 & 2.3 \\
\hline & & Total & & 824 & 132 & \\
\hline
\end{tabular}

*Years and Monthly of collection: 1999 (October and December) - 2001 (March, April, May and June) - 2003 (August and September) - 2004 (April, May, November and December) - 2005 (March, April, May, June, July, August, September, October and December) - 2006 January, February, March, April, May, June, July, August, September, October, November and December) 2007 (January, February, March, April, May, June, July, August, September, October, November and December), 2008 (January, February, March, April and May) and 2013 (November).

**Gregarious parasitoids (The percentage parasitism of each parasitoid species was calculated by means of the number of pupae parasitized per species of parasitoid, divided by the total number of pupae).

*** Percentage of parasitism. 
There were four specimens of Brachymeria podagrica (Fabricus) (Hymenoptera: Chalcididae); 25 of Trichopria sp. (Hymenoptera: Diapriidae); four of Hemencyrtus herbertii Ashmead (Hymenoptera: Encyrtidae); 56 of Nasonia vitripennis (Walker) (Hymenoptera: Pteromalidae); five of Paraganaspis egeria Díaz, Gallardo and Walsh (Hymenoptera: Figitidae); seven of Spalangia endius (Walker) (Hymenoptera: Pteromalidae); 30 of Pachycrepoideus vintemmiae (Rondani) (Hymenoptera: Pteromalidae); and one of Tachinobia sp. (Table 1).

The most frequent species was $N$. vitripennis, accounting for $42.4 \%$ of the individuals collected. This species behaves as gregarious parasitoid and is an ectoparasitoid in pupae of several species of Diptera families, particularly Calliphoridae, Muscidae, Sarcophagidae and Tachinidae (Rivers and Denlinger 1995). It is a polyphagous insect parasite over 68 species of Diptera (Whiting 1967, Marchiori 2013a, 2013b, Marchiori 2014b, 2014c).

The total frequency of parasitism was $1.6 \%$, probably due to the presence of gregarious parasitoids. Pachycrepoideus vindemmiae was the species that showed highest frequency of parasitism, possibly due to variations in the quality and availability of food resources or the density of hosts (Table 1).

Pachycrepoideus vindemmiae is considered to be a solitary parasitoid that controls a great number of Diptera in the families Anthomyiidae, Calliphoridae, Muscidae, Sarcophagidae, Tachinidae and Tephritidae. This species presents diversified (cosmopolitan) distribution and it has been found in North America and Africa (Gauld and Bolton 1988, Marchiori and Penteado-Dias 2010, Marchiori 2013a, 2013b, Marchiori et al. 2013).

The species B. podagrica occurs almost everywhere in the world and lives associated with Diptera synanthropic and other flies emerging from their pupae (Delvare and Boucek 1992, Marchiori 2001).

Several species of the family Encyrtidae have been successfully used in biological control programs. Hemencyrtus herbertii Ashmead (Hymenoptera: Encyrtidae) behaves as a parasitoid larvae, developing internally in the host body and emerging from the puparium (Noyes 1980, Gauld and Bolton 1988).

Diaz et al. (1996) found P. egeria immature stages of Diptera in Argentina (Diptera). According to these authors, in Brazil this species is found in the states of São Paulo and Mato Grosso do Sul.

Spalangia endius is a solitary parasitoid containing a great number of Diptera in the families Anthomyiidae, Drosophilidae, Calliphoridae, Muscidae, Sarcophagidae and Tephritidae (Hanson and Gauld 1995).

Species Tachinobia behave as gregarious parasitoid pupae of Lepidoptera and Diptera (Boucek 1977, La Salle 1994).

Species of the genus Trichopria are usually parasitoids of the immature stages of Diptera (Legner et al. 1976).

As an alternative to insecticides, insects called regulators can also be used as natural controls, both in agriculture and in animal breeding. Chemical control over insects in urban and rural environments is difficult because of the danger of contamination of humans, animals and the environment. Therefore, biological control of flies through using microhymenopterous parasitoids meets the need for alternatives for dealing with the problem, because of its safety, ease of handling and low cost (Silveira et al. 1989, Carvalho et al. 2003).

\section{Conclusion}

Nasonia vitripennis (Walker) (Hymenoptera: Pteromalidae) was the most frequent species with $42.4 \%$. The total frequency of parasitism was $1.6 \%$. Pachycrepoideus vindemmiae was the species that showed a highest percentage of parasitism.

\section{References}

Boucek, Z. (1977). Descriptions of Tachinobia gen. n. and species of Testrastichine (Hymenoptera: Eulophidae), with a tentative to genera. Bull Entomol Res., 67, 17-30. http://dx.doi.org/10.1017/S0007485300010853

Carvalho, A. R., Mello, R. P., \& D’Almeida, J. M. (2003). Microhimenópteros parasitoides de Chrysomya megacephala. Rev Saúde Públ., 37, 810-812. http://dx.doi.org/10.1590/S0034-89102003000600019

Delvare, G., \& Boucek, Z. (1992). On the new world Chalcididae (Hymenoptera). Mem Am Entomol Inst., 53, 30-31.

Díaz, N., \& Gallardo, F. (1996). Sobre cinipoideos del Brasil, parasitoides de dipteros estercoleros (Hymenoptera: Cynipoidea). Rev Soc Entomol Argent., 55, 127-126.

Greenberg, B. (ND). Flies and disease - ecology, classification and biotic association. New Jersey: Princeton University Press.

Gauld, I. D., \& Bolton, B. (1988). The Hymenoptera. Oxford: Oxford University Press. United Kingdom.

Hanson, P. E., \& Gauld, I. D. (1995). The Hymenoptera of Costa Rica. Oxford: Oxford University Press. 
LaSalle, J. (1994). North American genera of Testrastichine (Hymenoptera: Eulophidae). J Nat His., 28, 109-236. http://dx.doi.org/10.1080/00222939400770091

Legner, E. F., Moore, I., \& Olton, G. S. (1976). Tabular keys \& Biological notes to common parasitoids of synanthropic Diptera breeding in accumulated animal wastes. Entomol News., 87, 113-144.

Mabika, N., Masendu, R., \& Mawera, G. M. (2012). An initial study of insect succession on decomposing rabbit carrions in Harare, Zimbabwe. Asian Pac J Trop Biomed., 4, 561-569.

Marchiori, C. H, \& Penteado-Dias, A. M. (2010). Entomologia Forense: novas tendências e tecnologias nas ciências criminais. Rio de Janeiro: Technical Books Editora. Capítulo 9, parasitóides de dípteros de importância forense no Brasil (pp. 270-281).

Marchiori, C. H. (2001). Ocorrência de Brachymeria podagrica (Fabricius) (Hymenoptera: Chalcididae) como parasitóide de Peckia chrysostoma (Wiedemann) (Diptera: Sarcophagidae) no Brasil. Entomol Vectores., 8, 513-517.

Marchiori, C. H. (2013a). Parasitoids of Diptera of importance to public health, medical, veterinary and economic collected in two different types of traps in southern Goiás, Brazil. Mitt Klosterneuburg, 62, 23-28.

Marchiori, C. H. (2013b). Study of the attractiveness of their hosts by parasitoids in chicken. $J$ Pensée., 75 , 383-388.

Marchiori, C. H. (2014a). Diptera of economic and sanitary importance collected on different substrates in southern Goiás, Brazil. Int $J$ Sci Adv Technol., 1, 4-9.

Marchiori, C. H. (2014b). Parasitoid flies collected in the south Goiás and west Minas Gerais, Brazil. Sylwan., 6, 485-493.

Marchiori, C. H. (2014c). Parasitoides de dípteros associados com fezes bovinas nos Estados de Goiás e Minas Gerais. Jundiaí: Paco Editorial.

Marchiori, C. H., Borges, L. M. F., \& Ferreira, L. L. (2013). Hosts of the parasitoid Pachycrepoideus vindemmiae (Rondani) (Hymenoptera: Pteromalidae) of medical-veterinary and economic importance collected in the State of Goiás, Brazil. Am J Life Sci., 1, 228-231. http://dx.doi.org/10.11648/j.ajls.20130105.14

Marchiori, C. H., Vieira, C. I. S., Caldas, E. R., Teixeira, F. F., Silva, C. G., \& Linhares, A. X. (2000). Dípteros muscóides associados com fezes bovinas e seus parasitóides em Goiás. Arq Bras Med Vet Zootec., 52, 354-356. http://dx.doi.org/10.1590/S0102-09352000000400011

Noyes, J. S. (1980). A review of genera of Neotropical Encyrtidae (Hymenoptera: Chalcidoidea). Entomol Series, 41, 1-253.

Queiroz, M. M. C. (1996). Algumas características do comportamento reprodutivo e observações preliminares sobre o horário de oviposição de Chrysomya albiceps (Wiedemann (Diptera, Calliphoridae) em condições de laboratório. Rev Bras Entomol., 40, 133-136.

Radhakrishnan, S., Gopalan, A. K. K., Ravindran, R., Rajagopal, K., Sooryadas, S., \& Promod, K. (2012). First record of Chrysomya albiceps (Wiedemann, 1819) (Diptera: Calliphoridae) maggots from a sambar deer (Rusa unicolor) in Kerala, South India. J Parasit Dis., 36, 280-282. http://dx.doi.org/10.1007/s12639-0120110-7

Silveira, G. A. R., Madeira, N. G., Azeredo-Espin, A. M. L., \& Pavan, C. (1989). Levantamento de microhimenóptera parasitóides de dípteros de importância médico-veterinária no Brasil. Mem Inst Oswaldo Cruz., 84, 505-510. http://dx.doi.org/10.1590/S0074-02761989000800089

Whiting, A. R. (1967). The biology of the parasitic wasp Mormoniella vitripennis [Nasonia brevicornis] (Walker). Q Rev Biol., 42, 333-406. http://dx.doi.org/10.1086/405402

\section{Copyrights}

Copyright for this article is retained by the author(s), with first publication rights granted to the journal.

This is an open-access article distributed under the terms and conditions of the Creative Commons Attribution license (http://creativecommons.org/licenses/by/3.0/). 